\title{
The Formation of New Social Capital and Civic Engagement in Society 5.0 Viewed from Digital Citizenship Education
}

\author{
Anggi Yoga Pramanda ${ }^{1}$, Moh Muchtarom $^{2}$, Rusnaini $^{3}$ \\ \{anggiyoga03@student.uns.ac.id ${ }^{1}$, muhtarom1974@staff.uns.ac.id ${ }^{2}$, rusnaini@staff.uns.ac.id $\left.{ }^{3}\right\}$
}

Universitas Sebelas Maret, Surakarta, Indonesia ${ }^{1,2,3}$

\begin{abstract}
Entering the era of the industrial revolution 4.0, all areas of life are driven by technology and information. The impact of the industrial revolution 4.0 on the development of human interaction according to technological developments towards the era of society 5.0. This article discusses the concept of new social capital and civic engagement among residents of Kampung Cyber from the perspective of digital citizenship education. The method used in this research is qualitative descriptive analysis, data collection through interviews, observation, and literature study based on purposive sampling and snowball sampling techniques. The results of the study show that new social capital makes the internet a place to socialize. The internet is able to provide space for social capital in the post-modern era or it can be said as new social capital so that the internet also creates new types of social interaction and citizenship in society. This research is a form of Citizenship Education in the socio-cultural realm, that residents of Kampung Cyber in the existing reality through story experiences that are interwoven between user citizens and technology are online movements, entrepreneurship, volunteerism, and the economy so as to produce a process of forming civic engagement in the reality of society. cyberspace. These findings are particularly relevant for understanding the relationship between educational competence and digital citizenship.
\end{abstract}

Keywords: Social Capital, Civic Engagement, Digital Citzenship.

\section{Introduction}

In the era of the Industrial Revolution 4.0, each individual can easily build networks with other individuals without being limited by space and time. The internet, a product of advances in technology and information, has changed the pattern of human social interaction from face to face to community 5.0 mediated by devices. The concept of society 5.0 is not only limited to manufacturing factors but also solves social problems with the help of the integration of physical and virtual spaces [1]. The concept of society 5.0 is an answer to problems with the aim of justice, equity, and common prosperity so as to create a supersmart society [2]. Technology era society 5.0 creates a new value that will eliminate social gaps, age, gender, language and provide products and services that are specially tailored to the diverse needs of individuals and the needs of many people.

Cyber society is a term for internet users who actively interact, transact, search for information, or other activities online. The term cybersocial reality is an online life that can be analyzed with a sociological approach regarding its social structure and relations [3]. From Gotved's view, cybersocial can be formed from the participation of individuals or groups who carry out their activities continuously online so as to form patterns, actions and also the meaning of their actions. 
The study of the era of the industrial revolution 4.0 which is considered to have the potential to degrade the role of humans gave birth to a concept, namely society 5.0. Through this concept, it is hoped that artificial intelligence will transform big data collected through the internet in all areas of life into a new wisdom, with the hope of increasing human capacity in opening up opportunities for humans. The realization of society 5.0 aims to create a society where it can solve various social challenges by incorporating innovations in the industrial revolution 4.0, thus resulting in the formation of new social capital.

Online interactions can increase social capital be it bonding or bridging. However, there are two contradictory ideas regarding the impact of the internet on the individual social capital of its users. On the one hand, the internet allows individuals to expand their social networks thereby increasing social networks (Facebook which allows one to make friends with thousands of people). But on the other hand, the internet also complements the social environment around it so that the level of social capital ties in the offline environment can be reduced.

Putnam states that one of the ways to promote social capital is a neighborhood network, which is social engagement. This neighborly relationship can be in the form of mutual visits between friends and neighbors, social participation in the form of activities in public spaces such as meetings at recitation, social gathering, neighborhood association meetings and so on. The concept of social capital is very broad, covering issues of poverty alleviation, community development and the involvement of young citizens [4]. This active citizen involvement is an effort to improve the quality of life of the community both through political and non-political processes [5]. Besides being inclusive, social capital can also be exclusive at a certain level, thus becoming a barrier for members of the community outside the group to join and participate. Utilization of the existence of social capital in society has an influence on economic growth, health, education, welfare, government and governance

Formation The new social capital for the people of Kampung Cyber has the potential to be a good tool for Citizenship Education and to cultivate it in the aspect of civic engagement. In a social context, the era of digital citizenship requires citizens to be able to work and interact with other people in various circumstances and contexts. Citizens in the digital age must be able to engage in public debate and discussion, participate in community life, address problems and problems, direct them to treat others with respect whose ideas and values differ from their own.

\section{Methods}

The research method chosen is a qualitative method. Qualitative research examines participants' perspectives with interactive and flexible strategies. Qualitative research is aimed at understanding social phenomena from the participant's point of view. Thus qualitative research is research that is used to examine the conditions of natural objects where the researcher is the key instrument. The research location chosen was Kampung Cyber which is located at Taman KT I / 434, Patehan, Kraton District, Yogyakarta City, on the grounds that Kampung Cyber is one of the communities that has goals related to formation of new social capital in society 5.0. In this study, using field observation techniques, interviewing several informants in Kampung Cyber who were selected based on purposive sampling and snowball sampling techniques, including village administrators and several communities there. Interviews were conducted with several residents neighborhood association 36 and neighborhood association 36 administrators, direct observation of neighborhood association 36 community activities and literature study of literature discussing social capital, civic engagement and digital citizenship. 
In addition, this study uses literacy study methods as a complement to data. The validity test of the data used in this study used triangulation of sources. The qualitative data analysis that the researcher will use is based on the Miles and Huberman model [6] which consists of three activities, namely data reduction, data presentation, and drawing conclusions.

\section{Result and Discussion}

\subsection{Establishment of New Social Capital and Civic Engagement of the Kampung Cyber Community}

The growth of the internet with the presence of social media now has an impact on social capital, the existence of social media has opened new networks that offer so many opportunities. The internet is a technology product that is widely used by the community, the internet also raises new types of social interaction in society [7]. The benefits of online media can also provide additional income levels for economic actors in growing social capital with online communities, the presence of the internet has developed social capital in enriching human connections and networks [8].

Social capital is a set of informal values or norms that spread among group members that allow cooperation between them [9]. This cooperation occurs when members of the community meet mutual expectations. Social capital is also said to be the root of change hidden behind something [10].

Social capital in the online world can occur as a tendency for people to exchange information between individuals and groups, even in the online world social capital has a very strong level because usually in a community there will be activities that are usually planned [7]. In its development, social capital is dealing with the 4.0 industrial revolution. Therefore, social capital also experiences dynamics, so that their social capital also evolves with time. One of them manifested in the world of the internet. This is what is meant by new social capital.

The Kampung Cyber Program, which is also the neighborhood association 36 work program, has the goal of building neighborhood association 36 into an internet-based area. This Kampung Cyber is like a merger between the virtual community and the real community, because in real life they live together and in virtual life they form the same community. The majority of Kampung Cyber communities have private internet media access which is placed in their respective homes, so that individuals feel free to establish and do activities using the internet media. This effort in building the citizens' mindset to be technology literate is dominated by the awareness that appears subjectively, where the development of this cyber village is carried out independently by local villagers.

Efforts to form a cyber society carried out by citizens place social capital in every process, from planning, development to supervision. The implementation of social capital in the development of the cyber community is carried out in every aspect making Kampung Cyber an ideal example of the existence of cyber communities elsewhere. That way, Kampung Cyber can be an example for all parties who want to optimize the functions of the internet and social media, especially optimizing the function of social media in the realm of groups.

Social capital can function properly, of course, if the elements of social capital can be fulfilled. Three main elements, such as networks, norms, exchange and trust [11]. It is strengthened by the assumption from Francis Fukuyama that trust is the most important part of social capital or the main source that will determine whether social capital will be strong or 
weak [2]. If you look at the success of empowering the Kampung Cyber program on their lives, it can be assumed that there is a strong trust as social capital owned by residents of Kampung Cyber in the social life of the community. Trust in question is the public's trust in the initiator of the Kampung Cyber Program to make changes through various development efforts.

The social network among the residents of Kampung Cyber is formed between residents. As a community with a limited environmental background, not much effort can be made with people from outside the village, including to build networks. The community, who are mostly workers, do not have many opportunities to make exchanges with the outside world, especially with their limited education. The source of the existing network in Kampung Cyber comes from neighborhood association administrators. Neighborhood association administrators acts as a figure who has a wider social network than the village community. With the network they have, the neighborhood association administrators holds an important position in every Cyber Village program, namely as an idea originator and as an implementer of development.

An example of the success of building an internet network in Kampung Cyber is due to the support and cooperation between the neighborhood association administrators and those who understand the internet and the private sector. The social network owned by the neighborhood association management plays an important role in implementing the internet in Kampung Cyber, such as as a provider of suggestions or ideas, as a provider of tools and as a network management after the installation of the internet. With the development of internet access, Kampung Cyber has completely received the title as a progressive village in carrying out development. Currently the existence of the network in Kampung Cyber is getting wider with the recognition of Kampung Cyber as an internet village.

The City Government through the Koperasi and UMKM Office supports the village internet movement in Kampung Cyber by providing assistance in introducing Kampung Cyber products at every exhibition. With the recognition from the government, it is also a sign that Kampung Cyber has got a new network through a form of trust given by the government. Apart from the government, there are many parties who personally come to Kampung Cyber, especially academics who want to do studies or research. This situation makes Kampung Cyber stronger with the network it has.

Although it has its own characteristics as a traditional community group, there is also a tendency for other types of social capital. Currently, the people of Kampung Cyber tend to move towards a bridging typology. Bridging social capital has several principles that differentiate it from other typologies of social capital. The principles of bridging social capital are like that every member in a group has the same rights and obligations, each group decision is taken on the basis of an agreement with group members, while group leaders only carry out the results of group decisions [12]. From the existing principles, the type of social capital bridging refers to a society that recognizes the freedom of speech of each individual, recognizes human rights, deserves to be upheld and respected. Although social capital is part of community property, in this case social capital cannot be generalized to the behavior of the individual there [13]. This means that not all people in Kampung Cyber behave and take advantage of social capital as part of common property.

The Internet has provided new political information venues, sites for discussion, and networks for mobilization. Despite dire predictions by some that politics online would increasingly fragment the sense of political community or accelerate the decline in social capital [14], we find that internet use actually increases civic engagement. The results, civic engagement indicate that political information and communication online have visible collective benefits for society as well. Jefferson's republican ideal of civic virtue requires a knowledgeable citizenry, deliberative democracy through the frequent discussion of politics, and civic duty. 
Voting, though it is merely one form of participation, has a special place in a democratic society as the ultimate exercise of the rights and responsibilities of citizens. Civic engagement implies long-term changes in democratic participation, beyond involvement in any particular election. In an age where participation and civic engagement have been steadily declining, the internet may hold promise for renewing republican traditions of citizenship. Current and future benefits for more widespread information and mobilization are encouraging, especially given the greater use and political knowledge for young people online. In this capacity, the regular and effective use of the Internet is a potentially democratizing resource

\subsection{Kampung Cyber Program in Digital Citizenship Perspective}

The aspects of skills developed to equip citizens in the 5.0 society era include civic literacy, global citizenship, digital citizenship. First, civic literacy is focused on the knowledge and abilities of citizens in overcoming problems in social, economic, political and cultural contexts including how to solve social problems.

Second, global citizenship is a series of efforts to prepare citizens to have the ability to communicate and collaborate in relation to interactions between different cultures, sufficient basic knowledge related to aspects of geography, politics, economics, and science and the ability to understand problems and act with knowledge in an interdisciplinary manner and multidisciplinary.

The third aspect is digital citizenship through an understanding of security using the internet, knowing the internet, knowing how to find organize and create digital content, understanding how to play a role in increasing responsibility in intercultural interactions, and understanding the rights and obligations of using internet media. The third aspect becomes important and more urgent because the internet media is an entry point for applying civic literacy to a global world or global citizenship.

Kampung Cyber describes digital literacy efforts and the use of information and communication technology by residents for their daily lives, including improving their economy without intervention from the government or other stakeholders. Digital citizenship is the application of norms for the productive and appropriate use of technology that is relevant to today's technology-rich society and must be an integral part of technology education [15]. Digital citizenshiphas nine main elements to explain the use of technology in the digital age. These elements are categorized as digital access, digital commerce, digital communication, digital literacy, digital ettiqutte, digital law, digital rights and responsibilities, digital health and wellness, and digital security [16].

Implementation digital citizenship in Kampung Cyber, the emphasis is on the use of digital technology tools to support people's lives. Formationdigital citizenship done by fulfilling access to technology, access to health and security.

Table 1 : Element Digital Citizenship in Civic Engagement of Kampung Cyber

\begin{tabular}{ll}
\hline Element & Indicator \\
\hline Digital access & With the existence of an optical cyber network in every resident's house, the \\
& residents of Kampung Cyber can access information more easily. This is further \\
& developed with the presence of "SiWarga", administrative services are carried \\
& out through an online mechanism and provide information about the identity of \\
& residents and village news at any time.
\end{tabular}




\begin{tabular}{ll}
\hline $\begin{array}{l}\text { Digital health } \\
\text { and wellness }\end{array}$ & $\begin{array}{l}\text { The application "SiWarga" provides information on the blood groups of 151 } \\
\text { residents. So that if someone experiences a shortage of blood due to an accident, } \\
\text { the residents or neighborhood association administrators can ask residents with } \\
\text { the same blood to donate blood. }\end{array}$ \\
\hline Digital security. & $\begin{array}{l}\text { Since 2017, residents of Kampung Cyber can see spaces or places across the } \\
\text { village with CCTV. All residents can access the CCTV cameras. With the } \\
\text { existence of CCTV, it is an effort to provide security for the community and } \\
\text { anticipate crimes such as theft, etc. }\end{array}$ \\
\hline
\end{tabular}

Building digital citizenship, Citizenship Education emphasizes the development of citizens to have the attitude and willingness to interact with fellow citizens both in the community and cyberspace by always maintaining human dignity by having an attitude of sympathy and respect. Respect here is defined as a person's ability to be able to protect himself so as not to harm others. Citizenship Education learning in schools and colleges emphasizes the theoretical aspects of citizens and government as well as the relationship between citizens and citizens and citizens to the government. However, along with its development, there was an expansion of the meaning of Civics that went beyond the government mechanism by incorporating public welfare into it. Considering that the coverage of Citizenship Education is not only in school, but also exists and must live in the community (socio-cultural). Kampung Cyber program has the potential to be a good tool for civic education and to cultivate it in the civic engagement aspect. Kampung Cyber platform can add real understanding, with knowledge based on actual conditions in the field and then proceed with the hope that it can answer community needs, and involve collaboration between the community and the campus (school).

This research took place in Patehan Village, Yogyakarta City, where the main object of study was the Kampung Cyber Program. We can detect that online movement, entrepreneurship, volunteerism and economics are integrated into the Kampung Cyber Program. These things are civic engagement support if we refer to Jacoby's opinion again [17], this includes a wide range of activities, including developing civic sensitivity, participation in building civic society, and benefiting the common good. On the social side, the Kampung Cyber Program refers to actions to solve problems that exist in society and bring change to them.

The new social capital and civic engagement of the citizens of Kampung Cyber when viewed from the Republican Citizenship theory, republican citizenship emphasizes civic bonds which are different from individual bonds (liberal tradition) or group ties (communitarian tradition) [18]. While liberal citizenship emphasizes rights, republican citizenship emphasizes the obligations of citizens. In republican citizenship, individual freedom lies in the guarantee of state security which is under the rule of law and the kindness of these citizens in giving participation. So from the republican tradition, citizenship has ethical and legal dimensions. The legal status of each citizen is closely related to the ownership of privileges regarding rights and obligations towards the common interest or the public interest. Therefore, republican citizenship requires an active commitment in public affairs.

The communication process with residents is carried out through village deliberation media in a language that is easy to understand considering the low human resources of Kampung Cyber residents, so that from this process the residents understand the implementation of Kampung Cyber, and can be well received, therefore the residents are very supportive and show enthusiastic attitude. In its development until now, also socialization to the community and personal learning. To expand the transmission of information about the existence of cyber 
networks and their use, it is formed naturally through the media and routine forums that take place in the community.

The successful implementation of Kampung Cyber is also due to a good bureaucratic structure. In this case, there is a specialization in the division of tasks and authorities according to the competence that knows cyber problems neighborhood association 36 administrators who are very open, responsive, and oriented towards mutual consensus, thus creating good community participation. The establishment of Kampung Cyber was also motivated by complaints, ideas and criticism from the community, especially youth. In addition, it is also inseparable from the direct chain of relationships (chair of chomand) without any dividing boundaries between citizens, and levels of government above them, so that when cyber networks encounter obstacles, they can immediately ask for help from those who understand technology.

Despite the disparities in Internet use, there is cause for optimism. The rate at which individuals view political information online has been rising and continues to increase, especially for the young. The impact of digital citizenship is most profound for young people. The young a demographic group with the lowest civic and political participation have the highest probability of seeking online political news and becoming active in politics online. Because the young are more likely to have technology access and use online news [16], the consequences for the sustained engagement of future generations are significant.

This part revealed important evidence (measured with an interaction term) that online news may be especially beneficial for the young, related to increased political sophistication among this age group, and perhaps more permanent changes in civic engagement for the future. civic engagement provides a foundation for participation, based on an attachment to the political community, as envisioned by civic republicans. The next chapter addresses different forms of political communication on the Internet, to find out whether or how they can translate civic engagement into political participation.

\section{Conclusion}

The growth of the internet with the presence of social media nowadays has an impact on social capital, the existence of the internet has opened up new networks that offer so many opportunities. Technology can help people to build contacts and value into ourselves and technology has occupied a central position in social space which opens up wide opportunities for separate elements, so that new social capital is social capital that utilizes virtual social which makes the internet a place to socialize.

In the era of digital citizenship, efforts to respond to changes in global society and the challenges that accompany it by revitalizing Citizenship Education by preparing students to have economic competition, complex work productivity, global security, and the development of internet media are very crucial for the sustainability of democracy.

The authors found that educational attainment is related to the amount of time that people spend online, and that it is a stronger predictor of internet involvement in nonentertainment activities than variables such as race, ethnicity, or income. Controlling for other factors, education, years online, and youth are significantly associated with using the internet to enhance human capital (visiting web sites involving school, work, health, finances, or science) or social capital (visiting sites related to news, government, or politics). These findings are especially relevant for understanding the link between educational competencies and digital citizenship. 


\section{References}

[1] Skobelev, P \& Borovik, Y S, On The Way From Industri 4.0 to Industri 5.0 From Digital Manufacturing to Digital Society, International Scientific Research Journal, 2017.

[2] Fukuyama, F, Society 5.0: Aiming for a New Human-Centered Society, Japan Special ar, pp. 47-50, 2018.

[3] Gotved, S, The Construction of Cyber Social Reality. In D. Silver \& A. Massanari. Critical Cyber Cultural Studies, New York: New York University Press, 2006.

[4] Imandoust, Sadegh Bafandeh, Relationship between Education and Social Capital., Journal of Humanities and Social Science, 2011.

[5] Rusnaini, Service Learning dalam Komunitas Membangun Civic Resposibility di Indonesia, Seminar Nasional Penguatan Nilai-Nilai Kebangsaan Melalui Pendidikan Kewarganegaraan Persekolahan dan Kemasyarakatan, Surakarta, 2018.

[6] Sugiyono, Metode Penelitian Pendidikan ( Pendekatan Kuantitatif, Kualitatif, dan R\&D), Bandung: Alfabeta, 2015.

[7] Madhavan, E.S, Internet and Social Media's Social Movements Leading to New Forms of Governance and Policymaking: Cases From India, Journal of Culture, Politics and Innovation, Vol 1, 2016.

[8] Field, John, Modal Sosial, Yogyakarta: Kreasi Wacana, 2010.

[9] Fukuyama, F, Social Capital and Civil Society, International Monetary Fund Working Paper, 2000.

[10] Rasekhi, A \& Angadji, J S, The Effect of Social Participation of Social Capital Elements on National Unity in Iran., Journal of Currrent Research in Science, pp. 12-21, 2014.

[11] Chen, H \& Meng, T, Bonding, Bridging, and Linking Social Capital and Self-Rated Health Among Chinese Adults: Use Of The Anchoring Vignettes Technique,“ PLoS ONE, pp. 1-15, 2015.

[12] Hasbullah, Social capital: Menuju keunggulan budaya manusia Indonesia, Jakarta: United Press, 2006.

[13] Onyx, J \& Bullen, P, Measuring social capital in five communities, Journal of Applied Behavioral Science, pp. 23-42, 2000.

[14] Putnam, Robert, Bowling Alone:The Collapse and revival of American Community, Journal of Political Science and Politics, 2000.

[15] Ribble, Mike \& Bailey, G, Digital Citizenship In School, Washington DC: International Society for Technology in Education, 2004.

[16] Mossberger, Karen \& Caroline, J Tolbert, Digital Citizenship: The Internet, Society, and Partisipation, Cambride: MIT Press, 2008.

[17] Jacoby, Barbara \& Associates, Civic Engagement in Higher Education: Concepts and Practices, United States: Jossey-Bass A Wiley Imprint, 2009.

[18] Kartal, Filiz, Liberal and Republican Conceptualizations of Citizenship: A Theoretical Inquiry, Turkish Public Administration, Vol. 2728, 2016. 